\title{
Microalgae and Sustainability
}

\author{
Vanessa Kava ${ }^{1}$, José Viriato Coelho Vargas ${ }^{2 *}$, André Bellin Mariano² and Lygia Vitoria Galli-Terasawa \\ ${ }^{1}$ Genetics Department, Federal University of Paraná, Brazil
}

${ }^{2}$ Self-sustainable Energy Research \& Development Center, Federal University of Paraná, Brazil

Submission: April 18, 2018; Published: May 14, 2018

"Corresponding author: José Viriato Coelho Vargas, Self-sustainable Energy Research \& Development Center - NPDEAS - UFPR, PO Box 19011, 81531-980, Curitiba, Brazil, Email: vargasjvcv@gmail.com

\begin{abstract}
The evolution of aerobic metabolism and complex life on Earth was made possible by microalgae, that absorb carbon dioxide and release oxygen as a result of photosynthesis. Such organisms have conducted the process for more than 3 billion years, and currently are considered responsible for up to $60 \%$ of the global oxygen production. Furthermore, microalgae have been indicated as the most promising source of sustainable energy for the future. Energy generation from microalgae can occur in different ways, after biomass processing into biofuels (e.g., biodiesel, biohydrogen, biogas). Alternatively, many high valued compounds of interest can be obtained, such as food supplements to humans and animals, pharmaceutical and nutraceutical products, carotenoids derivatives, and even fertilizers. Microalgae cultivation does not compete with food crops for agricultural land, since they can be cultivated in compact photobioreactors (PBR) that can grow vertically, and use arid lands, requiring sunlight, water, and nutrients that could be supplied from effluents of the biodigestion of animal manure. In this mini review, some of the main applications of microalgae are presented, as well as some challenges that shall be overcome to make microalgae industrial utilization a possible future reality.
\end{abstract}

Keywords: Energy; Food supplements; Biorremediation; Biofuels; Pharmaceuticals; Compact photobioreactors

\section{Introduction}

Microalgae can be classified as a large group of microorganisms with a high degree of biological diversity, composed of prokaryotic organisms (cyanobacteria) and eukaryotic photoautotrophic protists [1]. However, divergences still prevail in the taxonomic classification of algae [2]. Thus, they are organized into groups, based on the composition of pigments, product storage profile and structural characteristics [3]. The industry sector attention has been increasingly attracted to microalgae derived biofuel since it is ecologically correct and potentially more productive than oil crops [4]. Microalgae can be grown in different systems, in volumes ranging from a few liters to billions of liters. In order to make possible any large-scale microalgae cultivation process, the need for a system with high productivity per occupied area, low cost of installation and operation is highlighted. The biodiversity of these organisms represents an important technological feature, allowing the cultivation of different species in a wide range of operational conditions. By way of illustration, we can cite a selfsustaining energy plant for biomass of microalgae production, in PBRs at the Self-sustainable Energy Research \& Development Center, NPDEAS, at the Federal University of Paraná, UFPR, in Curitiba, Brazil [5]. In that project, it was decided to study and develop the pilot-scale fish feed production process, from the microalgae residue that was previously used to produce biodiesel as the primary material [6], using compact PBRs developed by this research group and shown in Fig. 1. The design of this PBR is innovative and two patents have been submitted $[7,8]$.

In that scenario, the development of economically viable methodologies for microalgae derived bioproducts and biofuels would be very much appreciated. The discussion includes the microalgae biological characteristics and possible direct and indirect applications. To make the industrial use of microalgae technically and economically feasible, some possibilities as genetic improvement; the use of mathematical modeling and computational simulation tool for evaluating potential results are presented.

\section{Microalgae Utilization}

Microalgae are a group of organisms with a polyphyletic origin. To be identified as a microalgae, the organism must be small, unicellular or colonial, with little or no cellular differentiation, must have color, due to the presence of pigments, and occur mainly in water. In this way, microalgae are an artificial group, since it includes the so-called cyanobacteria, which belong 
to the Bacteria domain, but most species of microalgae belong to the Eukarya domain $[9,10]$.

Microalgae should be photoautotrophic, but not all the time, being also heterotrophic or mixotrophic. In the first, the functions are governed by photosynthesis, and in the heterotrophic cultivation, nutrients are made available for the metabolism to occur in the absence of light. And finally, in the mixotrophic culture both metabolisms mentioned above occur.

The exact number of species of microalgae is still unknown, and citations are found that there may be between 200,000 and a few million representatives of this group. This diversity makes microalgae a source of a wide range of chemicals with applications in the food, nutraceuticals, pharmaceuticals and cosmetics industries. The lipids accumulated by microalgae are classified according to the number of carbon atoms. Fatty acids with a chain of 14-20 carbons are used in the production of biodiesel, while those with larger chains are used as food supplements, such as eicosapentaenoic acid (EPA) and docosahexaenoic acid (DHA) [11]. In addition to lipids, microalgae have other valueadded metabolites, such as carbohydrates, proteins and pigments that can be refined and marketed with different applications. Carbohydrates are one of the most important microalgae compounds [11]. These compounds have high added value, with several applications. Some examples are the marketing of dietary supplements based on Chlorella and Spirulina, $\beta$ - carotene, phycobiliproteins, astaxanthin, oil rich in docosahexaenoic acid, among others. In this way, one must explore all the potentiality provided by microalgae biomass.

Microalgae are the main food of various species of fish, molluscs and crustaceans in natural environments. Because they are the primary marine producers, microalgae are essential for structuring almost all coastal and ocean ecosystems. The main use of microalgae in aquaculture is as a nutritional source, and can be used in natura or added to feed [6]. Protein content is the main component evaluated in the selection of microalgae for animal feed. However, when selected for in natura consumption, especially in the larval stage of aquatic organisms, they should have adequate size and shape to be ingested. Also, microalgae may be considered as a good alternative for animal consumption, but some metabolites produced by some species may have a toxic effect on some animals [6,12]. On the other hand, the improvement of the skin and fur of pets have been reported. In the case of feed for farmed animals, 5 to $10 \%$ of protein source may be microalgae, with no adverse consequences for the animals [12].

Both animal feeds and biofuels have as their main raw material agricultural products. This is one of the main aspects on which critics of the use of biofuels are based, i.e. the competition for agricultural land that should be primarily intended to produce human food. The increase in the global demand for fuels from renewable sources has leveraged many initiatives in the private and federal sectors, aiming at the production of biofuels, particularly in Brazil, the United States of America and Europe [13]. Globally, European biodiesel accounted for $43 \%$ of world production in 2011, being the world's largest producer of biodiesel, according to the United States Department of Energy. Total biodiesel production in Europe in 2013 was 10,367,000 tonnes [14]. It is interesting to highlight other advantages that result from the use of biodiesel, such as increased employment and useful coproducts obtained during the processing of this new fuel such as about $110 \mathrm{~kg}$ of glycerine for each ton of biodiesel [15].

According to Chisti [4] some microalgae may have up to $70 \%$ of lipids in their structure and are capable of producing more than 30 times the amount of oil per area of land, when compared to oilseed crops. The microalgae biomass doubling over a very short period of time, the use of a smaller physical space, the ability to grow in areas not suitable for agriculture and the least waste generation make this biofuel a promise of a clean energy source. The great challenge is to purify the lipid portion with the right properties for use as biodiesel. This process still requires a higher energy cost than the generated energy. In order to obtain a higher yield aiming at the economic viability of a microalgae-based energy system, hydrogen generation from photobioreactors such as those shown in Figure 1 can be included. It should be remembered that hydrogen is considered the fuel of the future, because it is renewable, its source is inexhaustible and does not generate any pollutant, and have the highest lower heating value (per unit of mass) among all known fuels possessing a high energetic capacity [16].

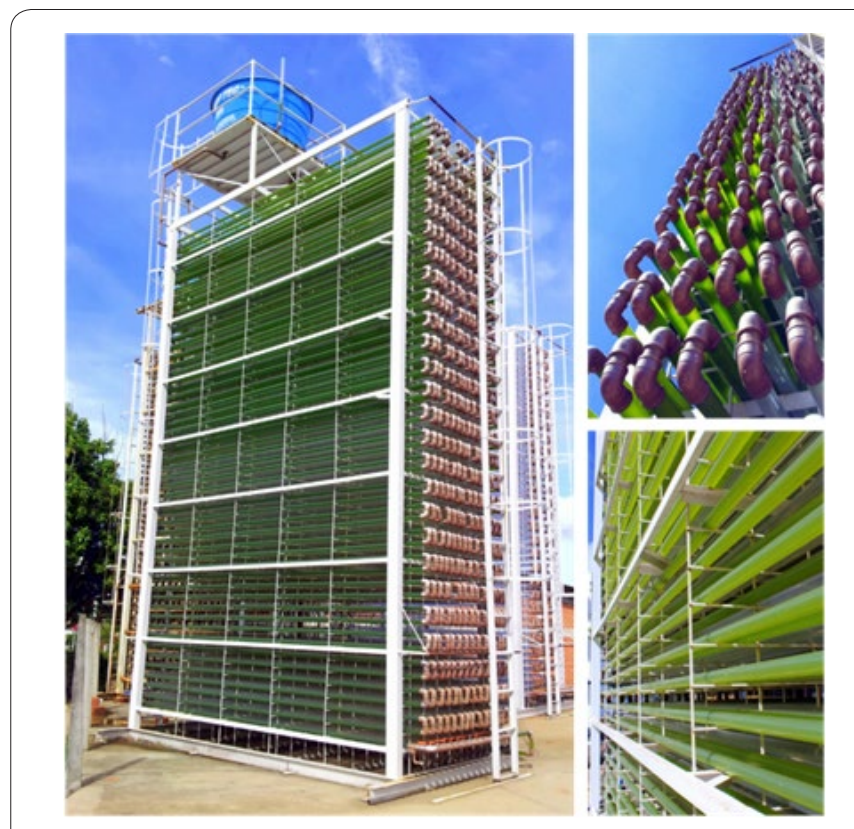

Figure 1: Compact photobioreactor for microalgae cultivation built at UFPR.

\section{Feasibility of microalgae derived biofuel industrial use}

Based on the positive aspects raised so far, it was to be expected that concrete technological and economic results for 
the use of microalgae as source of biofuels in the near future would be available. Stephens et al. [17] present two arguments that can explain why this has not yet occurred: (i) the pilot and demonstration plants are still below the economic feasibility scale, and ii) there was not enough time for the industry to evolve through the injection of recent capital into large-scale commercial production. In addition, another very important point regarding biofuels is the cost of oil. Whenever the price of the barrel is low, the economic advantages of renewable fuels decrease.

Once the optimum microalgae cultivation conditions have been reached, increasing the productivity of biofuels, biomass or any other bio-product can only be achieved with the genetic improvement of these organisms. The potential for genetic improvement of microalgae is enormous, there are many efforts in this regard, and in recent decades decades many advances have been achieved.

The genetic engineering tools have been adapted for microalgae. Strategies including increasing the number of copies of a gene, increasing or decreasing the expression of one or more genes, and still the expression of heterologous genes, selected from other species, are possible for several species of microalgae [18]. A variety of transformation methods have been used to transfer DNA to microalgae cells, including electroporation, biobalistics, and Agrobacterium tumefaciens, and the efficiency of the transformation is dependent on the species and the method used [19]. Some target genes have been identified and selected for genetic improvement, mainly after the publication of the genome of some species like Chlamydomonas reinhardtii [20-22]. Genetic modifications are now considered the great promise that could lead to an economically viable scenario for the production of clean energy and bio-products by microalgae. New technologies like genome edition using CRISPR (Clustered Regularly Interspaced Short Palindromic Repeats) are being applied with good results in microalgae, and with the advantage that the resulting mutants are not considered genetically modified organisms (GMOs), with less restrictions than GMOs regarding their use $[23,24]$.

The prediction of cultivation techniques results, even with microalgae wild or mutants species, is possible using mathematical modeling and computational simulation. In general, a mathematical model is designed to simulate the response or behavior of a real system in a computer, which allows to calculate the spatial and temporal distribution of any physical quantity within the physical system under study. These distributions are determined by the external environment conditions, fluid flow, physical system geometry, and internal system generation terms. Many mathematical models to predict the growth of microalgae in photobioreactors have been proposed $[25,26]$. As an example of recent progress, a mathematical model was presented by Kava-Cordeiro \& Vargas [27] to contemplate the possibility of genetic modification in microalgae to improve some aspect of interest (e.g., increase of lipid content, biohydrogen production).

\section{Conclusion}

Based on the arguments presented throughout this minireview, at the current moment of possible future shortage of energy and food resources to maintain human society's living standards, it is reasonable to think that microalgae could bring a possible solution to a sustainable world. In short, they were the organisms that transformed the inhospitable conditions of our planet into a life-friendly environment as we know it today. In fact, microalgae reproduce rapidly, they are the largest $\mathrm{CO}_{2}$ fixers on the planet, and they are at the bottom of the food chain. They generate huge amounts of biomass, so they are the largest known bioenergy store and have the potential to supply the energy needed to maintain a sustainable human society in an environmentally sound way, because it is renewable energy. With the presence of multi-generator and environmental remediation systems coupled with microalgae cultivation, it is expected to be possible to perform superior microalgae use in comparison with terrestrial cultures from all points of view, as well as to make microalgae commercially competitive in the production of biofuels and other products with high added value. However, it is not an easy goal to achieve. There are major technological challenges to be overcome in order to make possible the industrial use of microalgae with all the resources that can be obtained from these small but versatile organisms.

\section{Acknowledgement}

The authors gratefully acknowledge the support of the National Council for Scientific and Technological Development, CNPq, Brazil, projects 407198/2013-0, 403560/2013-6, and 407204/2013-0; contract 41-2013/UFPR/PSA-Peugeot-Citroen, and contract 111-2014/UFPR/NILKO Tecnologia Ltd.

\section{Conflict of Interest}

The authors declare that any economic interest or any conflict of interest do not exist.

\section{References}

1. Skjanes K, Rebours C, Lindblad P (2013) Potential for green microalgae to produce hydrogen, pharmaceuticals and other high value products in a combined process. Critical Reviews in Biotechnology 33(2): 172215.

2. Hegewald E, Bock C, Krienitz L (2013) A phylogenetic study on Scenedesmaceae with the description of a new species of Pectinodesmus and the new genera Verrucodesmus and Chodatodesmus (Chlorophyta, Chlorophyceae). Fottea 13: 149-164.

3. Lewis LA, Mccourt RM (2004) Green Algae and the Origin of Land Plants. American Journal of Botany 91(10): 1535-1556.

4. Chisti Y (2007) Biodiesel from microalgae. Biotechnology Advances 25(3): 294-306.

5. Satyanarayana KG, Mariano AB, Vargas JVC (2011) A review on microalgae, a versatile source for sustainable energy and materials. International Journal of Energy Research 35: 291-311.

6. Balen RE, Geraldo E, Luz Marques AEM, Cestari MM, Coelho Vargas JV, et al. (2015) Effect of defatted microalgae (Scenedesmus obliquus) 
biomass inclusion on growth performance of Rhamdia quelen (Quoy \& Gaimard, 1824). Journal of Applied Ichthyology 31(S4): 98-101.

7. Vargas JVC, Balmant W, Stall A, Mariano AB, Ordonez JC, et al. (2012) Photo-bioreactor for growing algae e.g. microalgae within nutrient medium, comprises support frame, horizontal bioreactor tubes, gassing/degassing housings, $\mathrm{pH}$ sensor, temperature sensor, and pump for circulating nutrient medium. Patent Number(s): US2012088296-A1 ; W02012050608-A1.

8. Vargas JVC, Miyawaki B, Mariano AB, Corrêa DO, Santos B, et al. (2013) Fotobiorreator tubular para tratamento integrado de efluentes líquidos e emissões. Patent number BR1020130263958.

9. Woese CR, Kandlert O, Wheelis ML (1990) Towards a natural system of organisms: proposal for the domains Archaea, Bacteria, and Eucarya. Proc Natl Acad Sci U S A 87(12): 4576-4579.

10. Baldauf SL (2008) An overview of the phylogeny and diversity of eukaryotes. Journal of Systematics and Evolution 46(3): 263-273.

11. Yen HW, Hu CI, Chen CY, Ho SH, Lee DJ, et al. (2013) Microalgae-based biorefinery - from biofuels to natural products. Bioresource Technology 135: 166-174.

12. Spolaore P, Joannis-Cassan C, Duran E, Isambert A (2006) Commercial applications of microalgae. Journal of Bioscience and Bioengineering 101(2): 87-96.

13. Eriksen NT (2008) The technology of microalgal culturing. Biotechnology Letters 30(9): 1525-1536.

14. European Biodiesel Board (EBB) (2015) The EU biodiesel industry statistics.

15. Behr A, Eilting J, Irawadi K, Leschinski J, Lindner F (2008) Improved utilisation of renewable resources: new important derivatives of glycerol. Green Chemistry 10(1): 13-30.

16. Preuster P, Alekseev A, Wasserscheid P (2017) Hydrogen storage technologies for future energy systems. Annual Review of Chemical and Biomolecular Engineering 8: 445-471.

17. Stephens E, Ross IL, King Z, Mussgnug JH, Kruse O, et al. (2010) An economic and technical evaluation of microalgal biofuels. Nature Biotechnology 28(2): 126-128.
18. Specht E, Miyake-Stoner S, Mayfield S (2010) Micro-algae come of age as a platform for recombinant protein production. Biotechnol Lett 32(10): 1373-1383.

19. Radakovits R, Jinkerson RE, Darzins A, Posewitz MC (2010) Genetic engineering of algae for enhanced biofuel production. Eukaryotic Cell 9(4): 486-501.

20. Dubini A, Ghirardi ML (2015) Engineering photosynthetic organisms for the production of biohydrogen. Photosynth Res 123(3): 241-253.

21. Merchant SS, Prochnik SE, Vallon O, Harris EH, Karpowicz SJ, et al. (2007) The Chlamydomonas genome reveals the evolution of key animal and plant functions. Science 318 (5848): 245-250.

22. Toepel J, Illmer-Kephalides M, Jaenicke S, et al. (2013). New insights into Chlamydomonas reinhardtii hydrogen production processes by combined microarray/RNA-seq transcriptomics. Plant Biotechnol J 11(6): 717-733.

23. Daboussi F (2017) Advances in editing microalgae genomes. Perspectives in Phycology 4(1): 17-23.

24. Kao PH, Ng IS (2017) CRISPRi mediated phosphoenolpyruvate carboxylase regulation to enhance the production of lipid in Chlamydomonas reinhardtii. Bioresour Technol 245(Pt B): 1527-1537.

25. Xu Y, Boeing WJ (2014) Modeling maximum lipid productivity of microalgae: review and next step. Renewable \& Sustainable Energy Reviews 32: 29-39.

26. Silva CEF, Bertucco A (2018) A two-stage system for the large-scale cultivation of biomass: a design and operation analysis based on a simple steady-state model tuned on laboratory measurements. Bioenergy Research DOI: 10.1007/s12155-018-9905-4.

27. Vargas JVC, Kava V, Balmant, W, Mariano AB, Ordonez JC (2016) Modeling microalgae derived hydrogen production enhancement via genetic modification. International Journal of Hydrogen Energy 41:8101-8110

\section{Your next submission with Juniper Publishers will reach you the below assets}

- Quality Editorial service

- Swift Peer Review

- Reprints availability

- E-prints Service

- Manuscript Podcast for convenient understanding

- Global attainment for your research

- Manuscript accessibility in different formats

( Pdf, E-pub, Full Text, Audio)

- Unceasing customer service

Track the below URL for one-step submission https://juniperpublishers.com/online-submission.php 